\title{
Hybridisation in a tropical seagrass genus, Halodule (Cymodoceaceae), inferred from plastid and nuclear DNA phylogenies
}

\author{
Y. Ito ${ }^{1}$ and N. Tanaka ${ }^{2}$ \\ ${ }^{1}$ Botanical Gardens, Graduate School of Science, The University of Tokyo, Tokyo, 112-0001, Japan \\ ${ }^{2}$ Tsukuba Botanical Garden, National Museum of Nature and Science, Tsukuba, 305-0005, Japan \\ Author for correspondence: ntanaka@kahaku.go.jp
}

\begin{abstract}
The tropical seagrass genus, Halodule, is distributed in warm to tropical areas throughout the world. We performed separate molecular phylogenetic analyses of Halodule based on both plastid and nuclear DNA sequences, followed by haplotype analysis, focusing on plants in the western Pacific area. One western tropical Atlantic species, H. wrightii s.l., and two western Pacific species, $H$. pinifolia and $H$. uninervis, were recognised and characterised by leaf morphology. Because samples from the western tropical Atlantic and the western Pacific were nested with each other, allopatric differentiation into both areas may have occurred during the early stages of the evolution of the genus. A hybrid of Halodule was detected at two nearby localities in Okinawa, Japan, together with its co-occurring maternal and paternal species, H. uninervis and $H$. pinifolia, respectively. Haplotype analysis provided evidence that the hybrid resulted from a single hybridisation event, followed by clonal dispersal to its present localities.
\end{abstract}

\section{Introduction}

Some submerged aquatic macrophytes are evolutionarily adapted to their environment through special pollination systems known as epi- and hypohydrophily. Under these systems, currents carry the pollen through the water or on the water surface. In the absence of reproductive incompatibility, hybridisation among two or more coexisting species is possible. In fact, epi- and hypohydrophilous aquatic macrophytes include natural hybrids, e.g., Callitriche (Callitrichaceae), Elodea and Najas (both Hydrocharitaceae), and Zannichellia (Potamogetonaceae) (Les \& Philbrick 1993), and Ruppia (Ruppiaceae) (Ito et al. 2010), but natural hybrids have not been found in seagrasses.

The seagrass genus, Halodule (Cymodoceaceae), is distributed in warm to tropical areas throughout the world and is thought to undergo epihydrophilous pollination according to Cox and Knox (1989), who observed the pollination of H.pinifolia in Fiji. The taxonomy of the genus has long been determined by examining leaf tip morphology and leaf width because of the absence of reproductive organs in most specimens. However, the taxonomic conclusions are inconsistent; den Hartog (1970) identified 
six species throughout the world by means of leaf tip morphology and leaf width, whereas Phillips and Menez (1988) identified three species using only leaf tip morphology. Taxonomic confusion has been especially prominent in the identification of $H$. uninervis; some researchers divided plants with narrow and wide leaves into $H$. tridentata and H. uninervis, respectively (den Hartog 1964, Ohba \& Miyata 2007), whereas others considered all plants with varying leaf width to be H. uninervis (den Hartog 1970, Phillips \& Menez 1988). Den Hartog (1964) attempted to use chromosomal information for the taxonomy of the genus, but only two specimens were examined; they were both $2 n=44$ and were thought to be tetraploid (den Hartog et al. 1979). Putative hybrids of Halodule have also been recognised in Japan on the basis of their sterility and intermediate leaf width when compared to their putative parental species (Ohba \& Miyata 2007), suggesting that a rather complicated evolutionary path may have led to this taxonomic confusion.

There have been two hypotheses for the evolution of Halodule: one is that, like the twin species of Syringodium (Cymodoceaceae) and Thalassia (Hydrocharitaceae) in the Atlantic and Pacific Oceans (Phillips \& Menez 1988), H. uninervis and H. wrightii may have originated from an ancestor with a wide distribution in tropical seas and differentiated in the respective oceans (Ostenfeld 1915, Setchell 1935), and the other is that the $H$. uninervis and $H$. wrightii groups may have been derived from the relict species H. pinifolia (den Hartog 1964). Although relationships within the genus Halodule have been investigated using isozyme (McMillan 1980) and DNA sequences (Waycott \& Barnes unpublished, Ohba, Ohba \& Miyata unpublished), relationships remain unclear and require further investigation.

The current study examined the phylogenetic relationship of Halodule species in the context of the widely accepted classification proposed by den Hartog (1970) and investigated the origin of the putative hybrid. We performed simultaneous molecular phylogenetic analyses using plastid (ptDNA, $r b c \mathrm{~L}$ ) and nuclear DNA (nDNA, phyB) gene sequences. For the putative hybrid, we performed subsequent haplotype analysis of psbA-trn $\mathrm{H}$ (ptDNA), focusing on western Pacific species. Finally, given the chromosomal information and morphological characteristics, we discuss the systematics and evolution of the genus.

\section{Materials and Methods}

\section{Taxon sampling}

Fifteen samples of Halodule species were collected from 11 localities, mainly in the western Pacific, but also in the western tropical Atlantic (Appendix 1). For phylogenetic comparisons, $r b c \mathrm{~L}$ sequences of Halodule were obtained from GenBank (241 bp of AY787476 + 488 bp of AY787477 for $H$. wrightii [Texas, USA], 1182 bp of U80689 for $H$. beaudettei [Florida, USA], and 1182 bp of U80690 for H. pinifolia [Western Australia, Australia]). AY952436 for $H$. uninervis was excluded because it was misidentified and should have been assigned to Zostera japonica (data not shown). Halodule uninervis and $H$. wrightii have also been reported in coastal areas of the eastern tropical Atlantic and Indian Oceans (Green \& Short 2003), but no high-quality specimens from either area, which would allow DNA extraction and analysis, were available. Most of the samples collected in the current study were identified morphologically according to 
den Hartog (1970) except one unidentified sample without leaf tips, which was treated as Halodule sp. Specimens of H. uninervis from two localities in Japan showed clear differences in leaf width. We tentatively referred to them as H. uninervis "Narrow" and H. uninervis "Wide," according to den Hartog (1970). Potamogeton maackianus A. Benn. (Potamogetonaceae) and Ruppia megacarpa S. Mason (Ruppiaceae) were selected as outgroups according to the phylogeny of Alismatidae presented by Les et al. (1997).

\section{Chromosome observations}

The somatic chromosome number of a subset of Halodule samples from two localities was obtained by light microscopic examination (Fig. 1). Root tips collected in the field were pretreated with $0.002 \mathrm{M} 8$-hydroxyquinoline at $4^{\circ} \mathrm{C}$ overnight, fixed with freshly mixed Carnoy's fixative (3:1 [(v/v)] ethyl alcohol: acetic acid) for at least $30 \mathrm{~min}$, and then preserved at $4^{\circ} \mathrm{C}$. For microscopic observation, root tips were soaked in $1 \mathrm{~N} \mathrm{HCl}$ for $1 \mathrm{~h}$ followed by $10 \mathrm{~min}$ at $60^{\circ} \mathrm{C}$. After immersion in tap water, the root tips were stained in a drop of $1.5 \%$ Orcein acetate solution on a slide glass and then squashed.

\section{DNA Extraction, Amplification, and Sequencing}

Total genomic DNA was extracted from silica gel-dried leaf tissue using the method of Doyle and Doyle (1987) with slight modifications after pretreatment with HEPES buffer ( $\mathrm{pH}$ 8.0) (Setoguchi \& Ohba 1995). Sequences determined in our current study were registered with the DNA Data Bank of Japan (DDBJ), which is linked to GenBank, and their accession numbers are given with the sample information in Appendix 1.

Target regions in plastid DNA were amplified by polymerase chain reaction (PCR) using the following primer pairs: rbcL_Z1 (Wolf et al. 1994) and rbcL_636R (P.G. Wolf http://bioweb.usu.edu/wolf/rbcL\%20primer\%20map.htm) or RM_F and RM_R (Ito et al. 2010) for $r b c \mathrm{~L}$ and $p s b \mathrm{AF}$ and $\operatorname{trn\mathrm {HR}}$ (Sang et al. 1997) for the $p s b \mathrm{~A}-\operatorname{trn\mathrm {H}}$ intergenic region. PCR amplification was conducted using TaKaRa Ex Taq polymerase (TaKaRa Bio, Shiga, Japan), and PCR cycling conditions were: $94^{\circ} \mathrm{C}$ for $60 \mathrm{sec}$, followed by 30 cycles at $94^{\circ} \mathrm{C}$ for $45 \mathrm{sec}, 52^{\circ} \mathrm{C}$ for $30 \mathrm{sec}$, and $72^{\circ} \mathrm{C}$ for $60 \mathrm{sec}$, followed by a final incubation at $72^{\circ} \mathrm{C}$ for $5 \mathrm{~min}$. The PCR products were digested with ExoSAP-IT (USB, OH, USA) and amplified using the ABI PRISM Big Dye Terminator v3.1 kit (Applied Biosystems, Foster City, CA, USA) with the same primers used for the initial PCR amplification reaction. DNA sequencing was performed using an ABI PRISM 377 DNA Sequencer (Applied Biosystems). Complementary electropherograms were compared by eye using the Genetyx-Win Version 3 software (Software Development Co. Ltd., Tokyo, Japan).

Nuclear-encoded phyB of the phytochrome gene family was selected as a nuclear marker because it is a single- or low-copy nuclear marker in several plant groups and thus advantageous for phylogenetic comparisons (Mathews et al. 2000, Simmons et al. 2001, Mathews \& McBreen 2008, Ito et al. 2010). PCR amplification was performed using either phyB_38F or phyB_RuppiaF (Ito et al. 2010) with B-down (Mathews et al. 2000) under the following conditions: $94^{\circ} \mathrm{C}$ for $60 \mathrm{sec}$, followed by 25 cycles at $94^{\circ} \mathrm{C}$ for $45 \mathrm{sec}, 60^{\circ} \mathrm{C}$ for $60 \mathrm{sec}$, and $72^{\circ} \mathrm{C}$ for $90 \mathrm{sec}$, followed by a final incubation at $72^{\circ} \mathrm{C}$ for $5 \mathrm{~min}$. The PCR products were purified using a GeneClean II kit (BIO 101, Carlsbad, CA, USA) and directly sequenced. Overlapping double peaks at the same sites were identified for complementary strands in electropherograms. PCR products 
with overlapping peaks were cloned using a TOPO TA Cloning kit for sequencing (Invitrogen Corp., Carlsbad, CA, USA). At least 16 clones per sample were chosen and their sequences were determined using the same procedure as used for the initial PCR amplification reactions, followed by direct sequencing. Clones containing nucleotides that were not detected by direct sequencing were regarded as PCR errors.

\section{Data analysis}

Multiple sequences of each gene were manually aligned because no length mutation was detected for $r b c \mathrm{~L}$ and $p h y \mathrm{~B}$. Phylogenetic analyses were independently performed for $r b c \mathrm{~L}$ and $p h y \mathrm{~B}$ because we detected some well-supported incongruence between genomes and because distinct sequences of phy B were obtained from two samples (NT2445 \& YI01240). One representative sequence per operational taxonomic unit (OTU) was used for the following phylogenetic analyses. Phylogenetic inference was performed using maximum parsimony (MP) and maximum likelihood (ML) in PAUP $^{\star} 4.0 \mathrm{~b} 10$ (Swofford 2002), as well as Bayesian inferences (BI) in MrBayes 3.1.2 (Ronquist \& Huelsenbeck 2003). In the MP analysis, a heuristic search was performed with 100 random addition replicates involving tree-bisection-reconnection (TBR) branch swapping, with the MulTrees option selected. The MaxTrees option was set at "no limits" for the analysis. Bootstrap analyses (Felsenstein 1985) were performed using 1000 replicates with TBR branch swapping and simple addition sequences. In the ML analysis, heuristic searches were performed with 10 random addition replicates using a best-fit model ( $\mathrm{HKY}+\mathrm{G}$ for $r b c \mathrm{~L}$ and $\mathrm{K} 80+\mathrm{G}$ for $p h y \mathrm{~B})$. Parameter values were estimated by a hierarchical likelihood ratio test in the program Modeltest 3.7 (Posada \& Crandall 1998). Bootstrap analyses were performed using 1000 replicates with TBR branch swapping and as-is addition sequences under the same ML models. In the Bayesian analysis, hierarchical likelihood ratio tests implemented in the program MrModeltest 3.7 (Nylander 2002) were used for substitution model selection (HKY + G for $r b c \mathrm{~L} ; \mathrm{K} 80+\mathrm{G}$ for $p h y \mathrm{~B}$ ). The Bayesian Markov chain Monte Carlo (MCMC) algorithm was applied for 1 million generations in both the $r b c \mathrm{~L}$ and $p h y \mathrm{~B}$ analyses, with four incrementally heated chains starting from random trees and sampling one out of every 100 generations. Of the $r b c \mathrm{~L}$ and $p h y \mathrm{~B}$ generations, the first $25 \%$ of trees (250,000 generations for both data sets) were discarded as burn-in, and the remaining trees were used to calculate a 50\% majority-rule consensus tree and to determine posterior probabilities for branches. The data matrices and the MP and Bayesian trees are available from the TreeBASE database (study accession http://purl.org/phylo/ treebase/phylows/study/TB2:S10689).

Statistical parsimony analyses of Halodule haplotypes from western Pacific samples were performed using the program TCS version 1.21 (Clement et al. 2000) with a 95\% parsimony connection limit. One insertion (six nucleotides) resulting from an inverted duplication of an adjacent sequence was coded as a single evolutionary event with the 'gaps $=5$ th state' option selected. 


\section{Results}

\section{Chromosome numbers}

A diploid genome with $2 n=44$ was observed in H.pinifolia (YI01241) and H. uninervis "Narrow" (YI01240) (Fig. 1, Table 1). This is in agreement with the number previously reported for H. wrightii from the western tropical Atlantic by den Hartog et al. (1979).

\section{Molecular Phylogeny}

In the current study, the sequences determined for $r b c \mathrm{~L}$ were comprised of the coding region, with a length of $1295 \mathrm{bp}$ for all samples examined. To adjust the length of the sequences, a portion of the amplified and GenBank sequences was discarded to give a total length of $1179 \mathrm{bp}$, except for one sequence of $H$. wrightii, for which the length was $792 \mathrm{bp}$ in total (AY787476 + AY787477). The molecular phylogenetic analyses yielded two MP trees (tree length $=115$ steps, consistency index $=0.9826$, retention index $=0.9375)$ and one ML tree with $-\mathrm{InL}=2264.6001$. Because the MP and ML trees showed largely congruent topologies, one of the two MP trees with branch support values derived from MP, ML and BI analyses is shown in Fig. 2A. In the tree, one branch and two clades were obtained and named RL-I to RL-III (Fig. 2A). RL-I contained $H$. wrightii and $H$. beaudettei from the western tropical Atlantic (96\%, 96\%, 1.00 for MP, ML bootstrap supports, and Bayesian posterior probability). The remaining samples from the western Pacific were divided into RL-II and RL-III (72\%, 56\%, 0.91); the former consisted of $H$. pinifolia, and the latter consisted of H. uninervis "Narrow," H. uninervis "Wide," and one sequence of $H$. pinifolia (U80690).

The sequence determined for $p h y \mathrm{~B}$ comprised a part of exon 1, with a length of 1050 bp for most samples (562bp for three samples and no sequences for two samples); the OTUs correspond to those shown in Fig. 2A. Of the 14 Halodule samples, two samples had two different $p h y \mathrm{~B}$ sequences each, whereas the others had a single $p h y \mathrm{~B}$ sequence. An identical MP tree (tree length $=321$ steps, consistency index $=0.9751$, retention index $=0.9158)$ and an ML tree with 2865.1418 were obtained, and the former is shown with branch support values derived from MP, ML and BI analyses in Fig. 2B. Three well-separated branches were obtained and named PB-I to PB-III (Fig. 2B). Samples were divided into PB-I and PB-II plus PB-III representing samples from the western tropical Atlantic and the western Pacific, respectively. PB-II and PB-III contained $\mathrm{H}$. pinifolia and $\mathrm{H}$. uninervis "Wide", and the heterogeneous phy $\mathrm{B}$ sequences of H. uninervis "Narrow" were placed in both PB-II and PB-III.

\section{Haplotype analysis}

Each fragment of psbA-trn $\mathrm{H}$ in Halodule was $282 \mathrm{bp}$, and $288 \mathrm{bp}$ in total after alignment according to Simmons and Ochoterena (2000), resulting in six haplotypes including five nucleotide substitutions and one indel variation (Table 2). All haplotypes were connected to the network constructed by TCS (Fig. 3). Two large clusters, haplotypes $\mathrm{A}$ and $\mathrm{B}$ and haplotypes $\mathrm{C}-\mathrm{F}$, were obtained. The former included those from $H$. pinifolia, and the latter included those from $H$. uninervis "Narrow" and "Wide". Halodule uninervis "Narrow" was comprised of haplotypes C, D, and F, and H. uninervis "Wide" was comprised of haplotype E. No haplotype sharing was obtained. Haplotype A was distributed widely from Japan to Singapore to Vanuatu, whereas haplotypes B, 


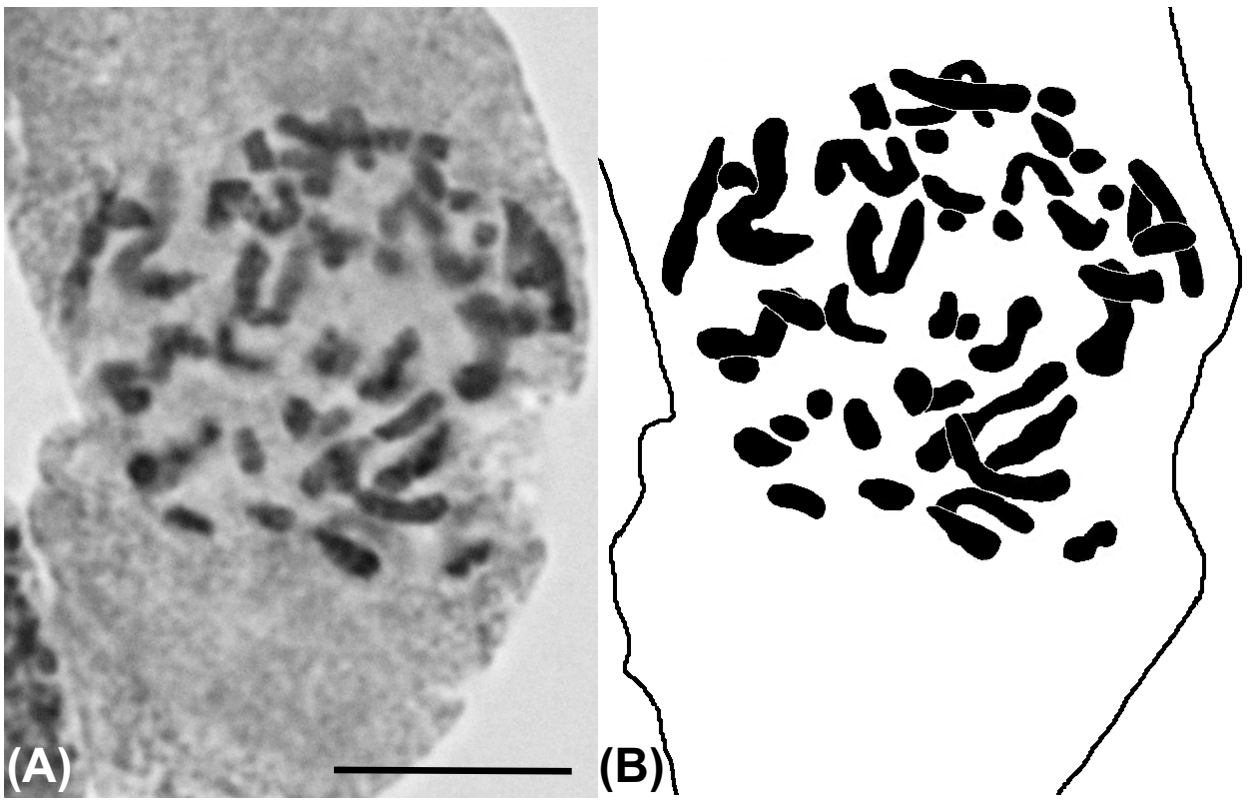

Fig. 1. Somatic chromosomes of the hybrid of Halodule. Bar indicates $10 \mathrm{~mm}$.

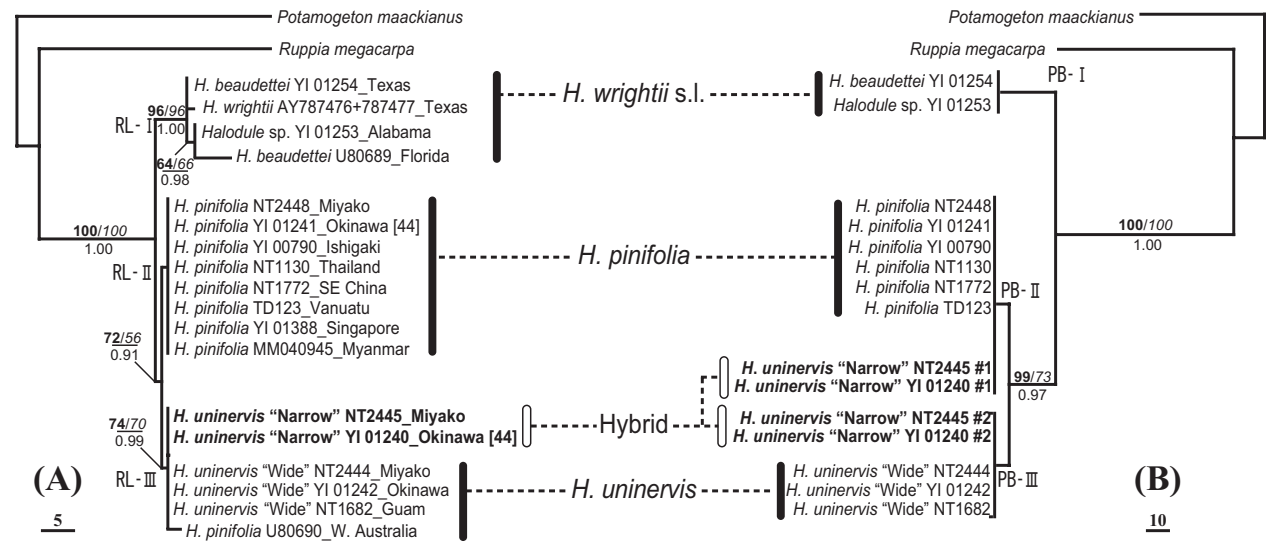

Fig. 2. The most parsimonious trees of Halodule based on (A) plastid DNA $(r b c \mathrm{~L})$ and (B) nuclearencoded $p h y \mathrm{~B}$ sequences. Samples collected in this study were identified by leaf morphology according to the taxonomic criteria of den Hartog (1970). DELTRAN optimisation was used for branch length measures of the phylograms. Numbers above the branches indicate bootstrap support calculated by maximum parsimony analysis, and those below indicate Bayesian prior probabilities. Samples in bold indicate those with heterogeneous phyB sequences. Chromosome counts are given in brackets beside accession numbers. 


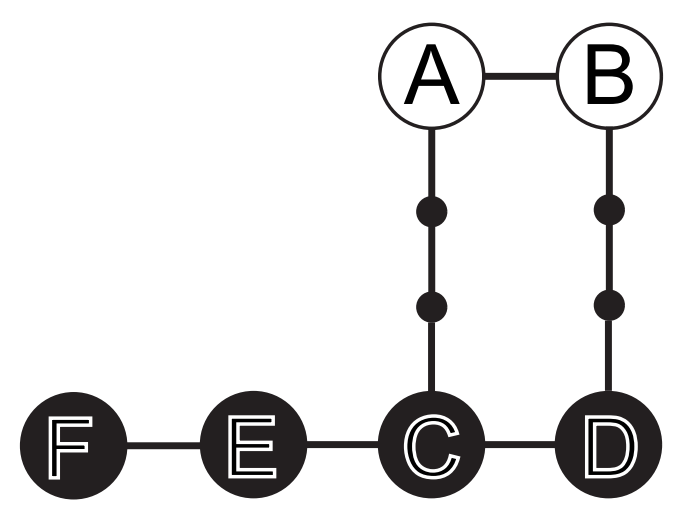

Fig. 3. Haplotype network of Halodule from the western Pacific based on $p s b \mathrm{~A}-\operatorname{trn} \mathrm{H}$ sequences. Haplotypes of $H$. pinifolia and $H$. uninervis plus the hybrid of Halodule are indicated with open and solid circles, respectively. Small solid circles indicate missing haplotypes. Each line connecting haplotypes indicates one mutational step.

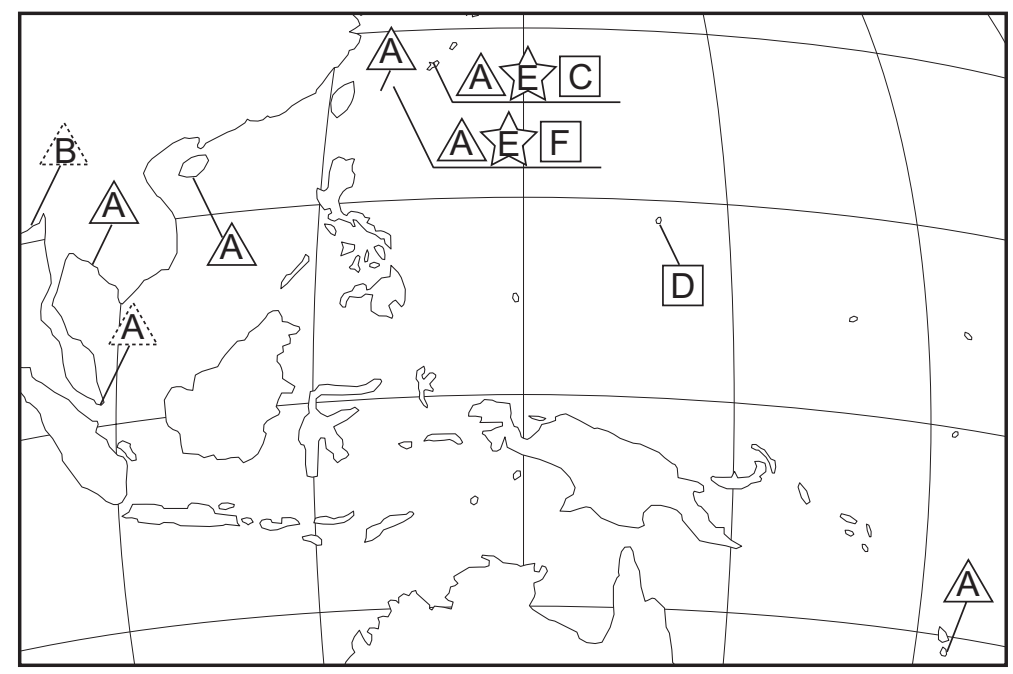

Fig. 4. Geographic distribution of Halodule in the western Pacific. Symbols indicate the samples examined in this study: H. pinifolia $(\Delta), H$. uninervis $(\square)$, and the hybrid of Halodule ( $\lesssim$ ). Haplotype letters are as in Fig. 3. The dotted triangles indicate specimens of H. pinifolia for which only plastid DNA was analysed. 
C, D, E, and F were restricted to Myanmar, Japan, Guam, Japan, and Japan, respectively. Multiple haplotypes were obtained in two localities in Japan; haplotypes A, C, and E were found in Amami and haplotypes A, E, and F were found in Okinawa (Fig. 4).

\section{Discussion}

In the present study, the separate molecular phylogenetic analyses of the $r b c \mathrm{~L}$ and phy $\mathrm{B}$ sequences partially resolved the phylogenetic relationships within Halodule. A comparison of the trees showed similarities, e.g., RL-II corresponded to PB-II, yet topological incongruence seems to be attributable to the fact that two samples had distinct phyB sequences (NT2445 and YI01240). When hybridisation and/or polyploidisation occur, similar topological incongruence between ptDNA and nDNA trees is often observed (e.g. Winkworth \& Donoghue 2004, Obbard et al. 2006, OhiToma et al. 2006, Kim et al. 2008, Ito et al. 2010). Given the inferred phylogenetic relationships, the systematics and evolution of the genus and the origin of a hybrid of Halodule are discussed below.

\section{Systematics and evolution of Halodule}

Molecular phylogeny resolved three clades that were comprised of (1) H. beaudettei and $H$. wrightii, (2) H. pinifolia, and (3) H. uninervis "Wide," and H. pinifolia (Fig. 2). The tridentate leaf tip of $H$. beaudettei was used by den Hartog (1970) to morphologically differentiate it from $H$. wrightii, which has a bicuspidate leaf tip, but the two were clustered in the $r b c \mathrm{~L}$ tree. McMillan (1980) elucidated a uniform pattern of isozymes based on an extensive study, mostly covering the distribution of $H$. beaudettei, H. wrightii, and two other local species in the western tropical Atlantic. He also investigated leaf width and leaf tip morphology. The current work suggests that, despite some genetic variation, $H$. beaudettei should be grouped together with $H$. wrightii and named $H$. wrightii s.l.

Although some genetic differentiation was observed, the results are also consistent with the Genbank accession U80690 of $H$. pinifolia being misidentified material of H. uninervis. The leaf width of $H$. pinifolia is $0.6-1.2 \mathrm{~mm}$ and that for H. uninervis is $0.25-3.5 \mathrm{~mm}$ (den Hartog 1970) and the emphasis he placed on these overlapping characters makes misidentification very easy. A similar confusion was observed in a previous molecular study, in which neither internal transcribed spacers (ITS) nor trnL trees resolved H. pinifolia and H. uninervis (Waycott \& Barnes unpublished).

Flowers and fruits have seldom been collected from Halodule specimens; thus, identification and classification are carried out using vegetative morphology. Along with the molecular data, we distinguished three species by leaf tip morphology, leaf width, and the length of the leaf sheath; $H$. pinifolia leaves exhibit a round, narrow $(0.3-0.9 \mathrm{~mm})$, and short (15.4-23.6 mm) morphology; H. uninervis leaves are tridentate, wide (2.1-2.7 mm), and short (8.0-30.9 mm), whereas H. wrightii s.l. leaves are bicuspidate or tridentate, narrow $(0.5-0.7 \mathrm{~mm})$, and long $(29.3-40.0 \mathrm{~mm})$ (Table 1). H. uninervis "Narrow" (NT2445 \& YI01240) has tridentate leaf tips, medium leaf width $(1.0-1.9 \mathrm{~mm})$, and medium leaf sheath $(21.8-37.0 \mathrm{~mm})$ and may be of hybrid origin (see below). 
Table 1. Systematics of Halodule with each morphological characters.

$\begin{array}{llllll} & \text { Hybrid } & \text { H. pinifolia } & \text { H. beaudettei } & \text { H. uninervis } & \text { H. wrightii* } \\ \text { Chromosome numbers (2n) } & 44 & 44 & - & - & 44 \\ \text { Geographic distributions } & \begin{array}{l}\text { western } \\ \text { Pacific }\end{array} & \begin{array}{l}\text { western } \\ \text { Pacific }\end{array} & \begin{array}{l}\text { western } \\ \text { tropical }\end{array} & \begin{array}{l}\text { western } \\ \text { tropical }\end{array} & \begin{array}{l}\text { western } \\ \text { Pacific }\end{array} \\ & & & \text { Atlantic } & \text { Atlantic } & \\ \text { Leaf tip } & \text { tridentate } & \text { round } & \text { tridentate } & \text { tridentate } & \text { bicuspicate } \\ \text { Leaf width } & \text { intermediate } & \text { narrow } & \text { narrow } & \text { wide } & \text { narrow } \\ \text { Length of leaf sheath } & \text { short } & \text { short } & \text { long } & \text { short } & \text { long } \\ \text { *den Hartog (1970). } & & & & & \end{array}$

Table 2. Nucleotide sequence variation and haplotypes of psbA-trnH in the Western Pacific Halodule.

$\begin{array}{lllllll}\text { Haplotype } & \text { (288 bp) } & & & & & \\ & 95 & 113-124 * & 142 & 150 & 151 & 226 \\ \text { A } & \text { G } & \text { ATAAAA } & \text { C } & \text { T } & \text { A } & \text { G } \\ \text { B } & \text { G } & \text { TTTTAT } & \text { C } & \text { T } & \text { A } & \text { G } \\ \text { C } & \text { G } & \text { ATAAAA } & \text { C } & \text { G } & \text { G } & \text { T } \\ \text { D } & \text { G } & \text { TTTTAT } & \text { C } & \text { G } & \text { G } & \text { T } \\ \text { E } & \text { T } & \text { ATAAAA } & \text { C } & \text { G } & \text { G } & \text { T } \\ \text { F } & \text { T } & \text { ATAAAA } & \text { A } & \text { G } & \text { G } & \text { T } \\ \text { * Asterisk indicates an inverted repeat. } & & & & & \end{array}$

An isozyme study of Halodule showed a clear difference between samples from the western tropical Atlantic and the Indo-Pacific (McMillan et al. 1981, McMillan 1991). A molecular phylogeny based on the ITS of nDNA also showed two clusters, one from the western tropical Atlantic and the other from the western Pacific (Waycott \& Barnes unpublished). Because samples from the western tropical Atlantic and the western Pacific were nested in the $r b c \mathrm{~L}$ and $p h y \mathrm{~B}$ trees (Fig. 2), allopatric differentiation between the western tropical Atlantic and the western Pacific clades may have occurred during the early stages of the evolution of the genus (Phillips \& Menez 1988). On the other hand, a molecular phylogeny of Halodule based on the trnL of ptDNA showed two clusters, one from the western tropical Atlantic and the western Pacific, and the other from only the western Pacific (Waycott \& Barnes unpublished).

Den Hartog (1979) considered $H$. wrightii to be tetraploid after comparing its chromosome number with other seagrasses, i.e., $2 n=20$ for Syringodium, $2 n=18$ for Thalassia. Our current study revealed the chromosome number of $H$. pinifolia to be $2 n=44$ (Fig. 1, Table 1), the same as that of $H$. wrightii (den Hartog et al. 1979). The copy number of $p h y \mathrm{~B}$ in most of the samples is one, suggesting all the Halodule species seem to be diploids, and thus polyploidisation has not occurred in the genus. 


\section{Hybridisation}

Hybridisation is common in aquatic plants but not in seagrasses (Les \& Philbrick 1993). Our current study detected a hybrid in the seagrass genus, Halodule, based on molecular analyses. This is evident because H. uninervis "Narrow" (NT2445 \& YI01240) harboured heterogeneous sequences, leading to their assignment to two different positions in the $p h y \mathrm{~B}$ tree, one with $H$. pinifolia and the other with $H$. uninervis (Fig. 2). Assuming maternal inheritance of chloroplast DNA in Halodule as reported for Potamogeton (Potamogetonaceae) (Kaplan \& Fehrer 2006), and given the $r b c L$ sequence identity between $H$. uninervis "Narrow" and $H$. uninervis "Wide", the hybrid was likely established by a cross between the maternal $H$. uninervis and the paternal $H$. pinifolia. This hybrid is morphologically characterised by the leaf width, which is intermediate between the parental species. Further comparison will be needed between the hybrid and $H$. tridentata from the western Pacific, a taxon that has been documented as a species (den Hartog 1964, 1970; den Hartog \& Kuo 2006) or a narrow-leaved variety of H. uninervis (den Hartog 1970).

The present haplotype analysis suggests that the hybrid resulted from a single hybridisation event, possibly in an area where $H$. pinifolia and uncollected $H$. uninervis with haplotype E coexisted (Fig. 4). It is likely that the hybrid was then dispersed to its present localities clonally or by seeds. Because the distributions of both $H$. pinifolia and H. uninervis broadly overlap in the western Pacific (Phillips \& Menez 1988), these species may coexist there. Ohba and Miyata (2007) identified a putative hybrid between $H$. tridentata (probably morphologically the same as $H$. pinifolia in our current study) and $H$. uninervis, in which $H$. tridentata-related $r b c \mathrm{~L}$ sequences shared identity with those of $H$. uninervis from Okinawa, Japan. Multiple origins of hybrids have been identified in the aquatic plant Potamogeton (King et al. 2001, Fant et al. 2003, 2005, Kaplan \& Fehrer 2006, Amano et al. 2008), suggesting multiple origins are also likely in Halodule. Further samples are needed to resolve details of the origin and evolution of this hybrid.

\section{Acknowledgments}

The authors thank J. Curtis, C.W. Martin, and S.M. Yaakub for providing materials, M. Ando, M. Nan-nichi, M. Shinoda, and S. Nagata for field assistance, and S. Kakishima for comments on the draft manuscript. We gratefully acknowledge grants to N.T. from the Ministry of Education, Culture, Sports, Science, and Technology (MEXT), Japan (21710248 and 21241055) and from a study project of the National Museum of Nature and Science: Integration of Systematics and Molecular Phylogenetics of All Groups of Organisms, and to Y.I. from Global COE Program (Integrative Life Science Based on the Study of Biosignaling Mechanisms), MEXT, Japan.

\section{References}

Amano M, Ohno M, Suda R, Iida S, Kadono Y \& Kosuge K (2008) Origin and present status of Potamogeton Xinbaensis in a natural population of Oitoike pond, Kitakyushu-City, Japan. Bunrui 8: 129-139. (in Japanese with English Abstract)

Clement M, Posada D \& Crandall KA (2000) TCS: a computer program to estimate gene genealogies. Molecular Ecology 9: 1657-1659. 
Cox PA \& Knox RB (1989) Two-dimensional pollination in hydrophilous plants: convergent evolution in the genera Halodule (Cymodoceaceae), Halophila (Hydrocharitaceae), Ruppia (Ruppiaceae), and Lepilaena (Zannichelliaceae). American Journal of Botany 76: 164-175.

den Hartog C (1964) An approach to the taxonomy of the sea-grass Halodule Endl. (Potamogetonaceae). Blumea 12: 289-312.

den Hartog C (1970) Halodule. Pp. 146-160 in den Hartog (ed.) The sea-grasses of the World. (North Holland, Amsterdam)

den Hartog C, van Loenhoud PJ, Roelofe JGM \& van de Sande JCPM (1979) Chromosome Numbers of three seagrasses from Netherlands antilles. Aquatic Botany 7: 267-271.

den Hartog C \& Kuo J (2006) Taxonomy and biogeography of seagrasses. Pp. 1-23 in Larkum AWD, Orth RJ \& Duarte CM (eds) Seagrasses: Biology, Ecology and Conservation. (Dordrecht, The Netherlands)

Doyle JJ \& Doyle JL (1987) A rapid DNA isolation procedure for small quantities of fresh leaf tissue. Phytochemical Bulletin 19: 11-15.

Fant JB, Kamau EM \& Preston CD (2003) Chloroplast evidence for the multiple origins of the hybrid Potamogeton $\times$ sudermanicus Hagstr. Aquatic Botany 75: 351-356.

Fant JB, Kamau EM \& Preston CD (2005) Chloroplast evidence for the multiple origins of the hybrid Potamogeton $\times$ fluitans. Aquatic Botany 83: 154-160.

Felsenstein J (1985) Confidence limits on phylogenies- an approach using the bootstrap. Evolution 39: 783-791.

Green EP \& Short FT (eds) (2003) World Atlas of Seagrasses. (Berkerley, University of California Press)

Ito Y, Ohi-Toma T, Murata J, \& Tanaka N (2010) Hybridization and polyploidy of an aquatic plant, Ruppia (Ruppiaceae) inferred from plastid and nuclear DNA phylogenies. American Journal of Botany 79: 1156-1167.

Kaplan Z \& Fehrer J (2006) Comparison of natural and artificial hybridization in Potamogeton. Preslia 78: 303-316.

King RA, Gornall RJ, Preston CD \& Croft JM (2001) Molecular confirmation of Potamogeton $\times$ bottnicus (P. pectinatus $\times$ P. vaginatus, Potamogetonaceae) in Britain. Botanical Journal of the Linnean Society 135: 67-70.

Kim S-T, Sultan SE \& Donogue MJ (2008) Allopolyploid speciation in Persicaria (Polygonaceae): insights from a low-copy nuclear region. Proceedings of the National Academy of Sciences, USA 105: 12370-12375.

Les DH \& Philbrick CT (1993) Studies of hybridization and chromosome number variation in aquatic angiosperms: evolutionary implications. Aquatic Botany 44: 181-228.

Les DH, Cleland MA \& Waycott M (1997) Phylogenetic studies in Alismatidae, II: Evolution of marine angiosperms (Seagrasses) and hydrophily. Systematic Botany 22: 443-463.

Mathews S, Tsai RC \& Kellogg EA (2000) Phylogenetic structure in the grass family (Poaceae): evidence from the nuclear gene phytochrome B. American Journal of Botany 87: 96-107.

Mathews S \& McBreen K (2008) Phylogenetic relationships of B-related phytochromes in the Brassicaceae: Redundancy and the persistence of phytochrome D. Molecular Phylogenetics and Evolution 49: 411-423.

McMillan C (1980) Isozymes of tropical seagrasses from the Indo-Pacific and the Gulf of Mexico-Caribbean. Aquatic Botany 8: 163-172.

McMillan C, Williams SC, Escobar L \& Zapata O (1981) Isozymes, secondary compounds and experimental cultures of Australian seagrasses in Halophila, Halodule, Zostera, Amphibolis and Posidonia. Australian Journal of Botany 29: 247-260.

McMillan C (1991) Isozyme patterning in marine spermatophytes. Pp. 193-200 in Triest L (ed.) Opera Botanica Belgica, vol. 4. (National Botanic Garden of Belgium, Meise, Belgium)

Nylander JAA (2002) MrModeltest v.1.0. Program distributed by the author. Department of Systematic Zoology, Uppsala University, Uppsala. (http://www.ebc.uu.se/systzoo/staff/ nylander.html) (Downloaded 30 October 2008) 
Obbard DJ, Harris SA, Buggs RJA \& Pannell JR (2006) Hybridization, polyploidy, and the evolution of sexual systems in Mercurialis (Euphorbiaceae). Evolution 60: 1801-1815.

Ohi-Toma T, Sugawara T, Murata H, Wanke S, Neinhuis C \& Murata J (2006) Molecular phylogeny of Aristolochia sensu lato (Aristolochiaceae) based on sequences of $r b c L$, matK, and phyA genes, with special reference to differentiation of chromosome numbers. Systematic Botany 31: 481-492.

Ohba T \& Miyata M (2007) Halodule. P. 101 in Ohba T \& Miyata M (eds) Seagrasses of Japan. (Hokkaido University Press, Sapporo, Japan)

Ostenfeld CH (1915) On the distribution of the seagrasses; a preliminary communication. Proceedings of the Royal Society of Victoria 27: 179-191.

Phillips RC \& Menez EG (1988) Seagrasses. Smithsonian contributions to the Marine Sciences, No. 34 (Smithsonian Institution Press, Washington DC).

Posada D \& Crandall KA (1998) Modeltest: testing the model of DNA substitution. Bioinformatics 14: 817-818.

Ronquist F \& Huelsenbeck JP (2003) MrBayes 3: Bayesian phylogenetic inference under mixed models. Bioinformatics 19: 1572-1574.

Sang T, Crawford DJ \& Stuessy TF (1997) Chloroplast DNA phylogeny, reticulate evolution, and biogeography of Paeonia (Paeoniaceae). American Journal of Botany 84: 1120-1136.

Setchell WA (1935) Geographic elements of the marine flora of the North Pacific Ocean. American Naturalist 69: 560-577.

Setoguchi H \& Ohba H (1995) Phylogenetic relationships in Crossostylis (Rhizophoraceae) inferred from restriction site variation of chloroplast DNA. Journal of Plant Research 108: 87-92.

Simmons MP, Clevinger CC, Savolainen V, Archer PH, Mathews S \& Doyle JJ (2001) Phylogeny of the Celastraceae inferred from phytochrome B gene sequences and morphology. American Journal of Botany 88: 313-325.

Simmons MP \& Ochoterena H (2000) Gaps as characters in sequence-based phylogenetic analyses. Systematic Biology 49: 369-381.

Swofford DL (2002) PAUP*. Phylogenetic analysis using parsimony ( ${ }^{\star}$ and other methods). Version 4.0b. (Sinauer Associates: Sunderland, Massachusetts)

Winkworth RC \& Donogue MJ (2004) Viburnum phylogeny: evidence from the duplicated nuclear gene GBSSI. Molecular Phylogenetics and Evolution 33: 109-126.

Wolf PG, Soltis PS \& Soltis DE (1994) Phylogenetic relationships of dennstaedtioid ferns: Evidence from rbcL. Molecular Phylogenetics and Evolution 3: 383-392. 
Appendix 1. Sample information of Halodule used in the current study. - denotes missing sequence. Herbaria abbreviations: The University of Tokyo = TI, Kochi Prefectural Makino Botanical Garden = MBK, National Museum of Nature and Science = TNS, National Herbarium of New South Wales $=$ NSW. Collector abbreviations: NT = N. Tanaka, SJ = Surrey Jacobs, Y = Y. Ito.

Taxon - Voucher; Location; GenBank accessions: $r b c \mathrm{~L}$, psbA-trnH, and phy $\beta{ }^{\mathrm{a}}=$ partially obtained sequences); haplotype; deposited herbaria; chromosome number

Halodule hybrid - NT2445; Miyakojima, Okinawa, Japan; AB571207, AB571193, AB571215: AB571221; E; TNS; $2 n=$ ?. YI01240; Kourijima Island, Nakijin Village, Okinawa, Japan; AB571206, $A B 571192, A B 571216: A B 571222 ; E ; T N S ; 2 n=44$

H. pinifolia (Miki) den Hartog - NT1160; East side of Peninsula, Rayong, Thailand; AB571204, AB571189, a ${ }^{A}$ 571217; A; TNS; $2 n=$ ?. NT1772; Hainan Isl., P.R. China; AB571203, AB571188, AB571211; ; TNS; $2 n=$ ?. NT2448; Miyakojima, Okinawa, Japan; AB571202, AB571187, AB571212; $A ;$ TNS; $2 n=$ ?. TD123; Vanuatu; AB571201, AB571186, a ${ }^{A}$ B571218; $A$; TNS; $2 n=$ ?. YI00790; Nagura wetland, Ishigaki Isl., Okinawa, Japan; AB571200, AB571185, AB571213; A; TNS; $2 n=$ ?. YI01241; Kourijima Island, Nakijin Village, Okinawa, Japan; AB571198, AB571183, AB571214; A; TNS; $2 n=44$. YI01388; Singapore; AB571199, AB571184, — ; $A$; TNS; $2 n=$ ?. NT et al. 040945; Yangon, Myanmar; $A B 571205, A B 571190,-; A ; M B K, T I ; 2 n=$.

$\boldsymbol{H}$. uninervis (Forsk.) Aschers. - NT1682; Guam, U.S.A.; AB571208, AB571192, AB571219; D; TNS; $2 n=$ ?. NT2444; Miyakojima, Okinawa, Japan; AB571209, AB571191, ${ }^{\mathrm{A} A B 571223 ;}$ TNS; $C ; 2 n=$ ?. YI01242; Kourijima Island, Nakijin Village, Okinawa, Japan; AB571210, AB571195, AB571220; F; TNS; $2 n=$ ?

$\boldsymbol{H}$. beaudettei den Hartog - YI01254; Texas Bay, Texas, USA; AB571197, - , AB571225; TNS; $2 n=$ ?

Halodule sp. - YI01253; Mobile Bay, Alabama, USA; AB571196, - , AB571224; TNS; $2 n=$ ?

Ruppia megacarpa S.Mason — SJ9712; Lakes Entrance, Victoria, Australia; AB507891, _ , AB508067; NSW.

Potamogeton maackianus A.Benn. - NT et al. 080052; Yae Aye Kan, Kalaw Township, Shan State, Myanmar; AB506769, - , AB559939; MBK, TI; $2 n=$ ?. 